\title{
Some Aspects of Population Dynamics of a Mytilid Musculista senhousia (BENSON) on Tidal Flats
}

\author{
TAEKO KIMURA and HIDEO SEKIGUCHI
}

Faculty of Bioresources, Mie University

\author{
河口干潟におけるホトトギスガイの個体群動態 \\ 木 村 妙子・関口秀夫 \\ (旧姓 山本)
}

\begin{abstract}
KIMURA TAEKO and HIDEO SEKIGUCHI (Faculty of Bioresources, Mie University). 1993. Some Aspects of Population Dynamics of a Mytilid Musculista senhousia (BENSON) on Tidal Flats. Benthos Research, $44: 29-40$.

Based on monthly sampling for three years on the tidal flats, some aspects of population dynamics of Musculista senhousia were examined. The spatio-temporal distribution of densities of the Musculista specimens indicated that the distribution was strongly patchy due to occurrence of dense colonies of the small-sized juveniles, and to their mass mortality caused by sporadic heavy rains coupled with typhoons. Therefore, the number and size of the cohorts showed considerable annual fluctuations. It can be concluded that the cohort establishment of $M$. senhousia in the flats does not depend directly on strength of the recruitment, while collapsing of the cohorts and/or failure of the recruits are caused by catastrophic episodes of physical disturbance.
\end{abstract}

\section{Introduction}

The mytilid Musculista senhousia (BENSON) has been found in the western Pacific from Siberia through China and Japan to southeast Asia (MOR. TON, 1974). The species is reported from the coasts of Hokkaido, Honshu and Kyushu in Japan (KU. RODA et al., 1971). The species, which was introduced before 1944 from Japan into the United States, is also known from the Pacific coasts from Washington to central California (ABOTT, 1974).

Musculista senhousia often forms large colonies

Received July 3, 1991 : Accepted November 27, 1992 which almost completely enclose the individuals and are anchored in position by a well-developed byssus (MORTON, 1974 ; ITO \& KAJIHARA, 1981a, b). In Japan the species is found on mud sediments down to $20 \mathrm{~m}$ water depth, and sometimes in seagrass beds (KURODA et al., 1971). The species forms dense colonies with up to 10,000 inds. $/ \mathrm{m}^{2}$ on tidal flats in estuarine and inlet waters with the progress of eutrophication (e.g., the innermost part of Tokyo Bay and the Lake Hamana). Its density shows remarkable annual fluctuations (TAKI, 1952 ; UCHIDA, 1965 ; CHIBA PREFECTURAL FISHERIES EXPERIMENTAL STATION, 1965 ; HAMAMATSU HighsChOOL BIOLOGY ClUB, 1983). Formation of 
large colonies of the species changes environmental conditions for the local benthic assemblages, sometimes making other bivalve populations important for fisheries collaps (KIKUCHI \& TANAKA, 1978; FUROTA, 1981).

Several important papers on the ecology of $M$. senhousia including the population dynamics for one year and over are published since 1974 (MORTON, 1974 ; KIKUCHI \& TANAKA, 1978 TANAKA \& KIKUCHI, 1978 ; ITO \& KAJIHARA, 1981a ; XU, 1983). Of these studies, a pioneer work of TANAKA \& KIKUCHI (1978), which was done based on monthly sampling for six years on the subtidal zone at Tomoe Cove, Amakusa, made clear the longevity, recruitment and growth vital for understanding population dynamics of the species.

The purpose of the present study is to examine the spatio-temporal distribution of the densities, and the number and size of the cohorts of M. senhousia based on monthly sampling for three years on the intertidal flats in the western part of Ise Bay along the Pacific coasts of central Japan.

\section{Materials and Methods}

\section{Study area}

The Ano and Shitomo Rivers located in Tsu City flow into the western part of Ise Bay along the Pacific coast of central Japan. The saline water is detected in the Ano River from the river mouth to a weir $2.3 \mathrm{~km}$ upstream, while in the Shitomo River from the mouth to a point of $5.5 \mathrm{~km}$ upstream. The present study was done for the three years (from April, 1987 to September, 1989) on the tidal flats extending from the mouth upstream to about 1.5 $\mathrm{km}$ of these two rivers (Fig. 1). Despite the mouths of these small rivers being adjacent, the flats of the rivers show different types of sediment which will be mentioned in the later section.

Data of air temperature and rainfall at $\mathrm{Tsu}$ City, and of salinity in the surface water at a site close to the study area are shown in Fig. 2.

\section{Sampling and processing of benthos}

Five series of sampling (Table 1) were carried out during the three years (April, 1987 to Septem- ber, 1989), the first two series of sampling for examining spatial distribution of $M$. senhousia in relation to environmental conditions, and the others for making clear spatio-temporal distribution of densities of the species and then for identifying its cohorts. Sampling stations are indicated in Fig. 1. All samples of sediment were obtained near MLWS at low tide, and were fixed in $10 \%$ formalin after sieving with $1 \mathrm{~mm}$ mesh-openings. Any animal was sorted out from the samples and was identified to a species level.

Shell length of the Musculista senhousia specimens was measured in a minimal scale of $0.1 \mathrm{~mm}$ with a slide caliper or an ocular micrometer. AKAMINE (1985)'s method was applied to the length data of the specimens to separate the polymodal length distribution into two or more normal distributions. Then the growth curves of different cohorts were inferred by following the mean length of the obtained individual normal distributions.

\section{Measuring of environmental conditions}

The granulometric characteristics and ignition loss of the sediments in the upper $2 \mathrm{~cm}$ at sampling stations were measured as follows. After the sediment was dried in air for several days in the laboratory, a sample of $100 \mathrm{~g}$ dry sediment was filtered with a series of sieves of $4.0 \mathrm{~mm}, 2.0 \mathrm{~mm}, 1.0 \mathrm{~mm}$, $0.710 \mathrm{~mm}, 0.560 \mathrm{~mm}, 0.350 \mathrm{~mm}, 0.250 \mathrm{~mm}, 0.177 \mathrm{~mm}$, $0.125 \mathrm{~mm}, 0.088 \mathrm{~mm}, 0.063 \mathrm{~mm}$ and $0.044 \mathrm{~mm}$ meshopenings. The sediment retained by each sieve was weighed. Based on grain size distribution of the sediments, the median and mean grain size $(50 \phi$, $\mathrm{MZ} \phi$ ), and the sorting coefficient $\left(\sigma_{\mathrm{t}}\right)$ were calculated according to FOLK and WARD (1957):

$$
\sigma_{\mathrm{t}}=\frac{\phi 84-\phi 16}{4}+\frac{\phi 95-\phi 5}{6.6}
$$

High values of the sorting coefficient indicate decreasing of variations in grain size. Fractions of the silt-clay $(<0.063 \mathrm{~mm})$ and the shell fragments ( $\geqq 2.0 \mathrm{~mm}$ ) were also weighed. After sieving the sediments with mesh-openings of $1.0 \mathrm{~mm}$, the finer sediment fraction from each station was dried at $95^{\circ} \mathrm{C}$ for 12 hours, and then the ignition loss, generally regarded as indicating organic matter content, 


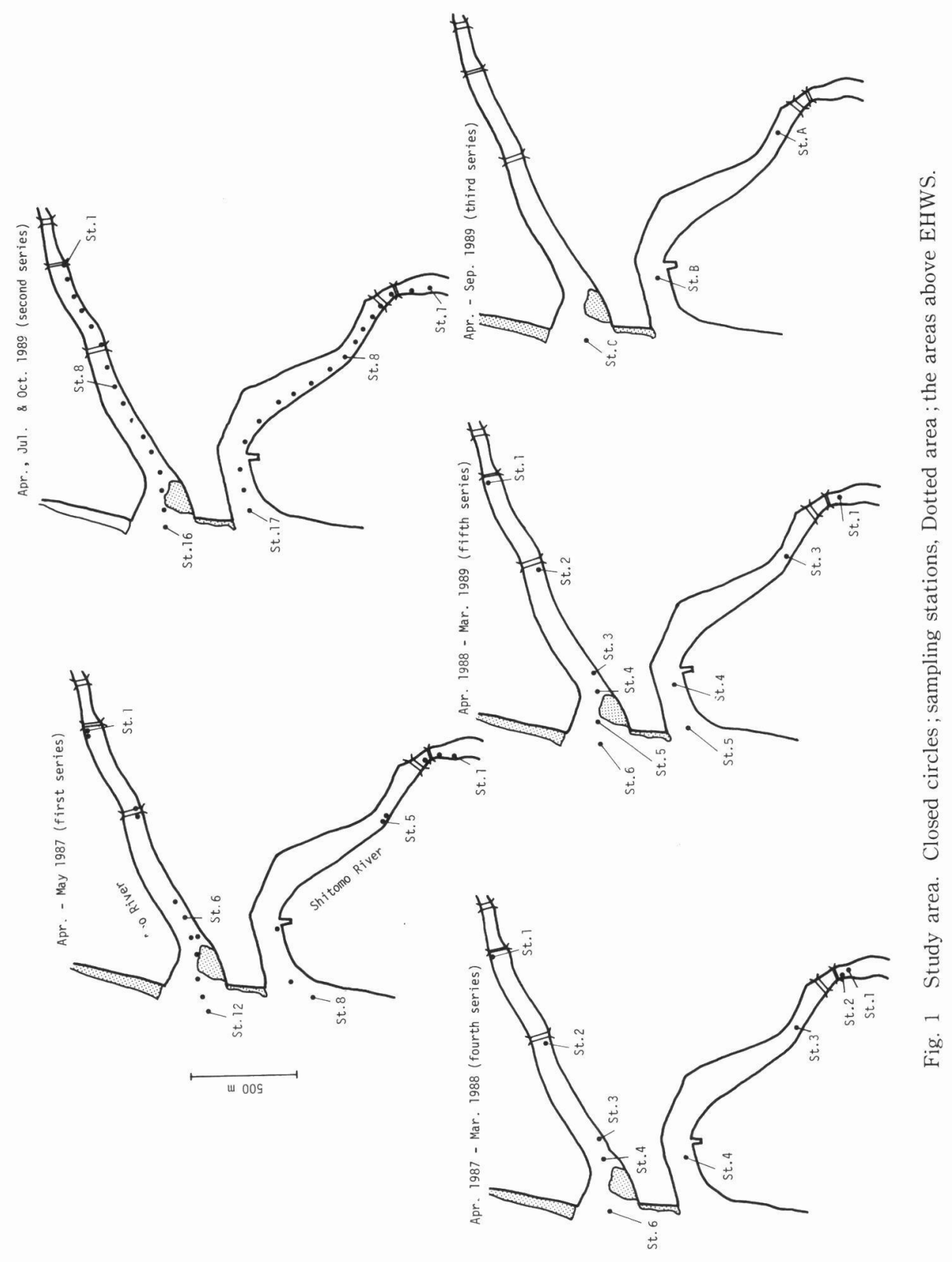



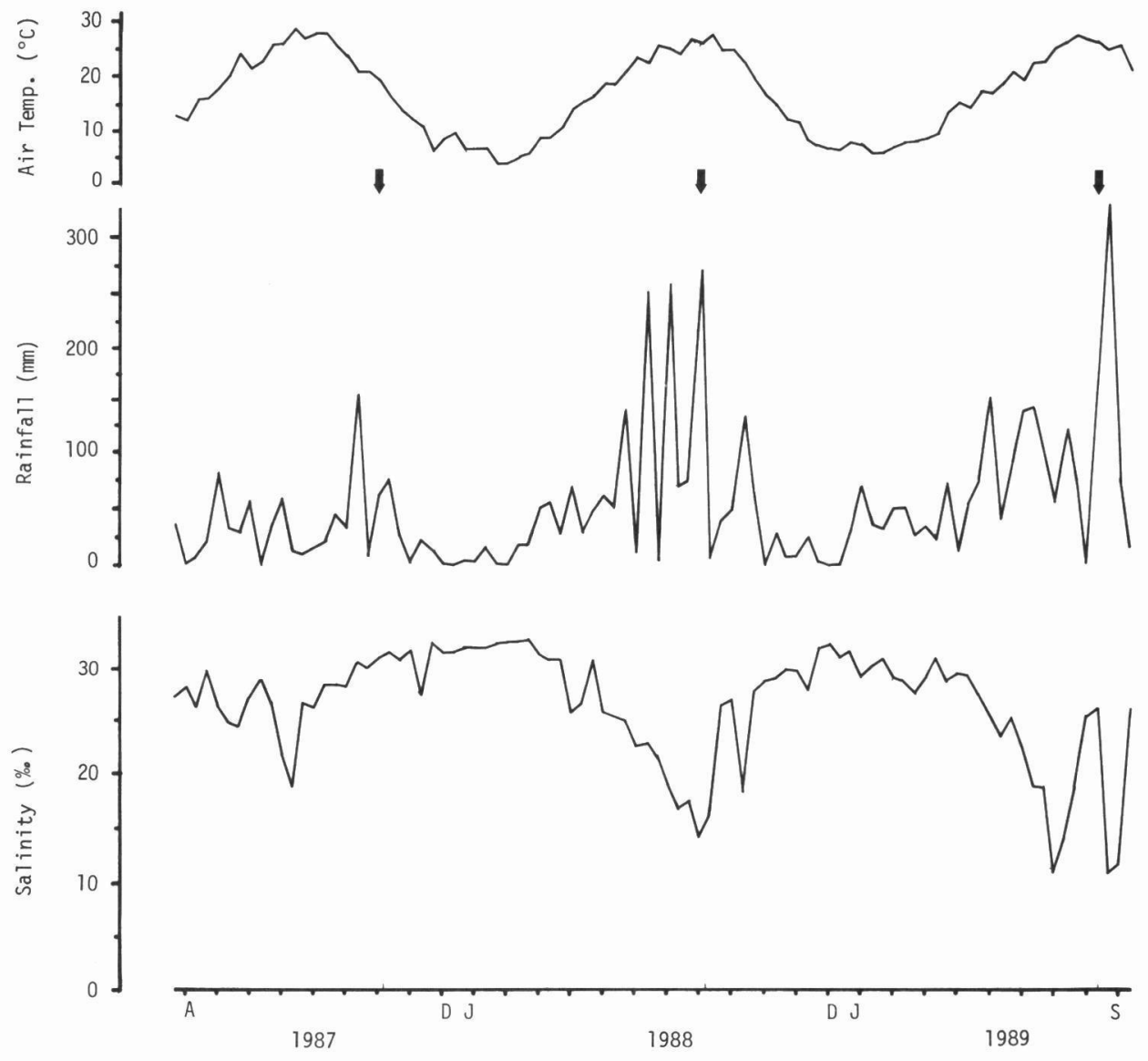

Fig. 2 Air temperature, rainfall and salinity of the surface waters for the surveyed period. Air temperature was averaged over every 10 days, and rainfall was integrated every 10 days. Arrows indicate typhoons passing close to Tsu City.

was measured after burning at $850^{\circ} \mathrm{C}$ for an hour in an electric oven.

The sediment in the upper $30 \mathrm{~cm}$ at the sampling stations was obtained with a transparent acrylic corer. The RPD (depth of the redoxpotential layer), recognized by an abrupt change from light color into black colour in the sediment layers, was recorded.

\section{Results and Discussion}

1. Environmental conditions of the studied area and the occurrence of $M$. senhousia (first and second series of sampling)

Environmental conditions of the tidal flat sedi- ments and the occurrence of the $M$. senhousia specimens in the Ano and Shitomo Rivers were examined in April, 1989 (second series of sampling) (Fig. 3) when a marked change of weather conditions was not observed for the previous several months (see Fig. 2). In the Ano River, the average grain size varied from very coarse sand to very fine sand $(-0.60 \leqq$ phi median diameter $\leqq 3.38)$ or from very coarse sand to very coarse silt $(-0.41 \leqq$ phi mean diameter $\leqq 0.486$ ). The silt-clay content was largest $(28.68 \%)$ at the most upstream station, where the sorting is also relatively good. On the other stations silt-clay content was rather low $(0.05$ to $6.35 \%$ ). The ignition loss varied from 0.43 to 3 . 
Table 1 Data for sampling the tidal flat sediments in the Ano and Shitomo Rivers

\begin{tabular}{|c|c|c|c|c|}
\hline Series & Surveyed period & \multicolumn{2}{|c|}{$\begin{array}{c}\text { Number of sampling } \\
\text { stations }\end{array}$} & Sampling methods \\
\hline \multicolumn{5}{|c|}{ Data for distribution of $M$. senhousia in comparison with sedimentological data } \\
\hline \multirow[t]{2}{*}{1} & April, May, '87 & Ano R. & 12 & one sample at each stn. \\
\hline & & Shitomo R. & 8 & $25 \times 25 \times 10 \mathrm{~cm}$ quadorat \\
\hline \multirow[t]{2}{*}{2} & April, July, Oct., ' 89 & Ano R. & 16 & two samples at each stn. \\
\hline & & Shitomo R. & 17 & $\begin{array}{l}\text { cylinder with a diameter of } 15.5 \mathrm{~cm} \text {, } \\
20 \mathrm{~cm} \text { deep }\end{array}$ \\
\hline \multicolumn{5}{|c|}{ Data for density fluctuation and cohort analyses } \\
\hline \multirow[t]{2}{*}{3} & April to Sept., ' 89 & Ano R. & 1 & five samples at each stn. \\
\hline & & Shitomo R. & 2 & $\begin{array}{l}\text { every sample } 2 \mathrm{~m} \text { apart each other } \\
\text { near MLWS cylinder with a diameter } \\
\text { of } 15.5 \mathrm{~cm}, 20 \mathrm{~cm} \text { deep monthly sam- } \\
\text { pling }\end{array}$ \\
\hline \multirow[t]{2}{*}{4} & April, ' 87 to March, ' 88 & Ano R. & 5 & one sample at each stn. \\
\hline & & Shitomo R. & 4 & $\begin{array}{l}25 \times 25 \times 10 \mathrm{~cm} \text { quadrat monthly sam- } \\
\text { pling }\end{array}$ \\
\hline \multirow[t]{2}{*}{5} & April, ' 88 to March, ' 89 & Ano R. & 6 & one sample at each stn. \\
\hline & & Shitomo R. & 4 & $\begin{array}{l}25 \times 25 \times 10 \mathrm{~cm} \text { quadrat monthly sam- } \\
\text { pling }\end{array}$ \\
\hline
\end{tabular}

$37 \%$. Shell fragments were detected solely at a middle stream station in a negligible amount. The RPD layer generally occurred close to the surface sediment and again below the $23 \mathrm{~cm}$ depth.

In the Shitomo River, the grain size varied between medium sand and very fine sand $(0.26 \leqq \mathrm{phi}$ median diameter $\leqq 3.15 ; 0.37 \leqq$ phi mean diameter $\leqq$ 3.35). Silt-clay content varied between 0.02 and 34 . $29 \%$. The ignition loss $(0.47$ to $11.27 \%)$ roughly correlated with the silt-clay content. The shell fragments were found at 6 stations. The highest shell fragment content was recorded at a down. stream station (12.70\%) where Ruditapes philippinarum and Crassostrea gigas fragments were identified. In other five stations shell fragments consisted of Musculista senhousia. The RPD layer was in the upper $18 \mathrm{~cm}$.

In general, grain size was smaller and the silt-clay content was higher in the Shitomo River than in the Ano River.

In the Ano River, Musculista senhousia occurred abundantly in the downstream area in April and
May, 1987 (first series of sampling), but was not found in April, 1989 (Fig. 3), when the above sedimentary analysis was carried out, as well as in July and October 1989 (second series of sampling). In the Shitomo River, two groups of colonies of abundant $M$. senhousia occurred nearly $800 \mathrm{~m}$ apart, one at the upstream stations, and the other at the downstream stations in April, 1989 (Fig. 3). These two colonies also occurred in other months of the first and second series of sampling except October, 1989 (Fig. 4). In general, the species was more abundant in the Shitomo River than in the Ano River (Figs. 3 and 4).

Because $M$. senhousia occurred only in the Shitomo River when the sediment condition was analysed, the comparison between these was only possible for this river. Although occurrence of the $M$. senhousia colonies did not show a clear-cut relation with a specific type of the sediment conditions, it seems to be coupled with relatively high organic content and relatively high silt-clay fraction of the flat sediments in the Shitomo River. But in the 


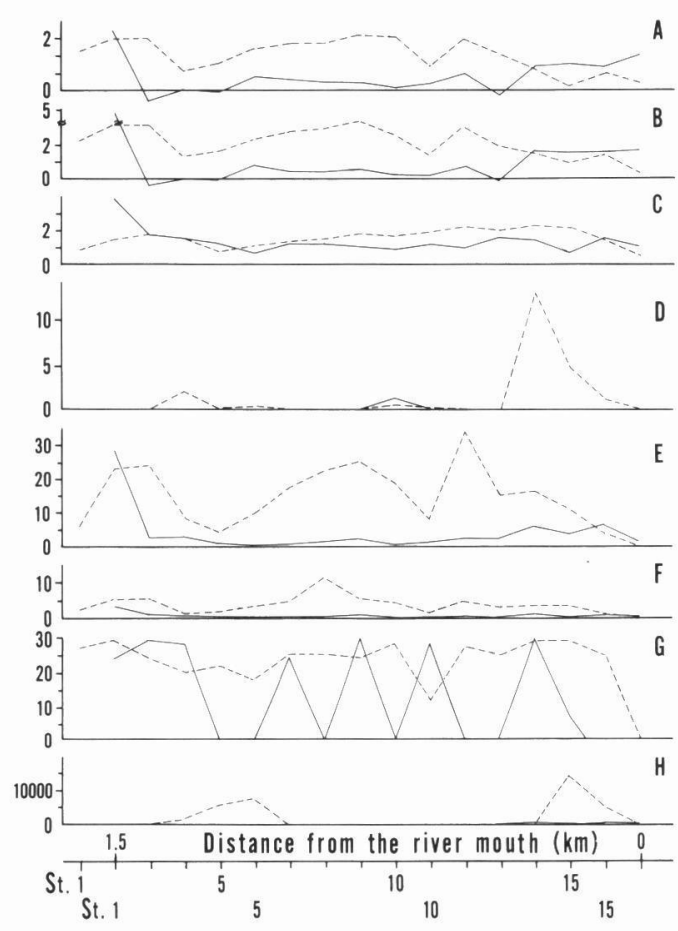

Fig. 3 Environmental conditions of the intertidal flat sediments in the Ano and Shitomo Rivers in April, 1989. A ; median grain size $(50 \phi)$, B mean grain size $(\mathrm{MZ} \phi), \mathrm{C}$; sorting coefficient, D; fraction of shell fragments (\%), E; silt-clay fraction (\%), F; organic content (\%), G; depth of the redox-potential layer $(\mathrm{cm}), \mathrm{H}$; Musculista senhousia (inds. $/ \mathrm{m}^{2}$ ). Solid lines ; the Ano River, Dotted lines; the Shitomo River. The stations refer to the second series of sampling (Fig. 1).

stations with extremely high silt-clay fraction colonies were not found (Figs. 3 and 4).

\section{Fluctuation of densities of the M. senhousia specimens (third to fifth series of sampling)}

The spatio-temporal fluctuations of density of the $M$. senhousia specimens, based on monthly sampling in the Ano and Shitomo Rivers for the three years, are shown in Figs. 5 and 6. Seasonal and annual changes of density of the specimens were remarkable: It varied strongly between the two rivers and even among the adjacent stations in each river. In particular the species was scarce in the Ano River after August, 1988, while M. senhousia continued to form colonies in the Shitomo River.

In the Ano River, the species was scarcely found at Stns. 1 to 3 and 5 to 6 (Fig. 1) for the surveyed period. Dense colonies with more than 40 , 000 inds. $/ \mathrm{m}^{2}$ small-sized juveniles $(2-6 \mathrm{~mm}$ in shell length) appeared at Stn. 6 (=Stn. C in the third series of sampling) in the downstream in August, 1987. It, however, disappeared two months later due probably to flashing out by heavy rain associating with a typhoon. The species occurred most stably and most densely at Stn. 4 for a comparatively long period with more than 1,000 inds. $/ \mathrm{m}^{2}$, and its maximum density attained more than 6,000 inds./ $\mathrm{m}^{2}$. Heavy rains caused by a typhoon in July and August, 1988 greatly changed topographic features of the mouth of the Ano River, so that these colonies disappeared in July, 1988 onward.

In the Shitomo River, the species was scarcely found at Stns. 1 to 3 and 5, though the colonies with 1,000 inds. $/ \mathrm{m}^{2}$ were detected several times at Stns. 1 and 3. These colonies were composed mainly of the small-sized juveniles. The species was most common and most dense at Stn. 4 (=Stn. B in the third series of sampling) for the surveyed period, particularly dense colonies with more than 5,000 inds. $/ \mathrm{m}^{2}$ (15,000 inds. $/ \mathrm{m}^{2}$ in maximum) were found several times (in September, 1987, April to May, 1988, November, 1988 to February, 1989 as well as April and July, 1989). Heavy rains coupled with a typhoon in April, 1988 killed these dense colonies, and many dead shells were deposited there. New colonies were again formed there in October afterwards. These small colonies were composed mainly of the small-sized juveniles $(2-6 \mathrm{~mm}$ in shell length).

Shell length composition of the $M$. senhousia specimens, which contained the length data of the samples collected at all the stations in the two rivers from April, 1987 to September, 1989, is shown in Fig. 7. In the surveyed area, the main recruit- 
Ano River

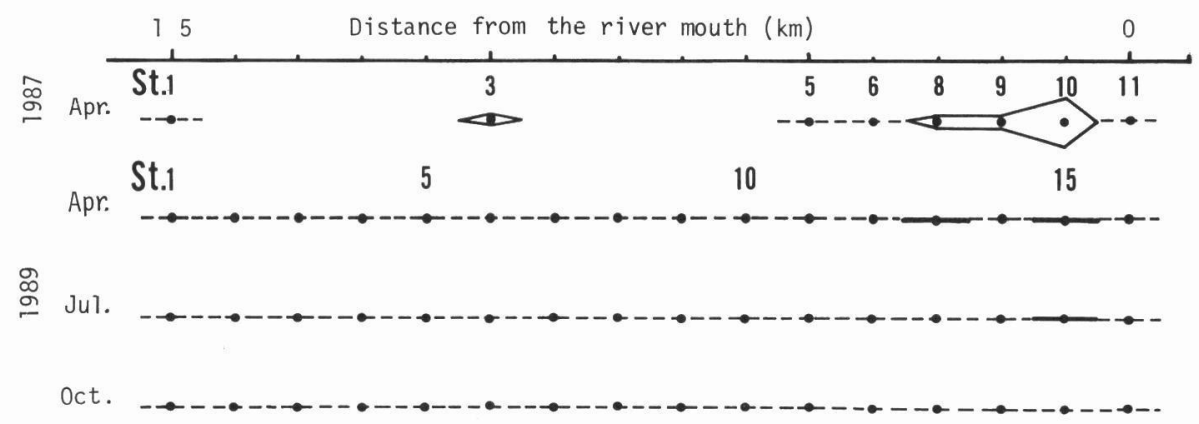

Shitomo River
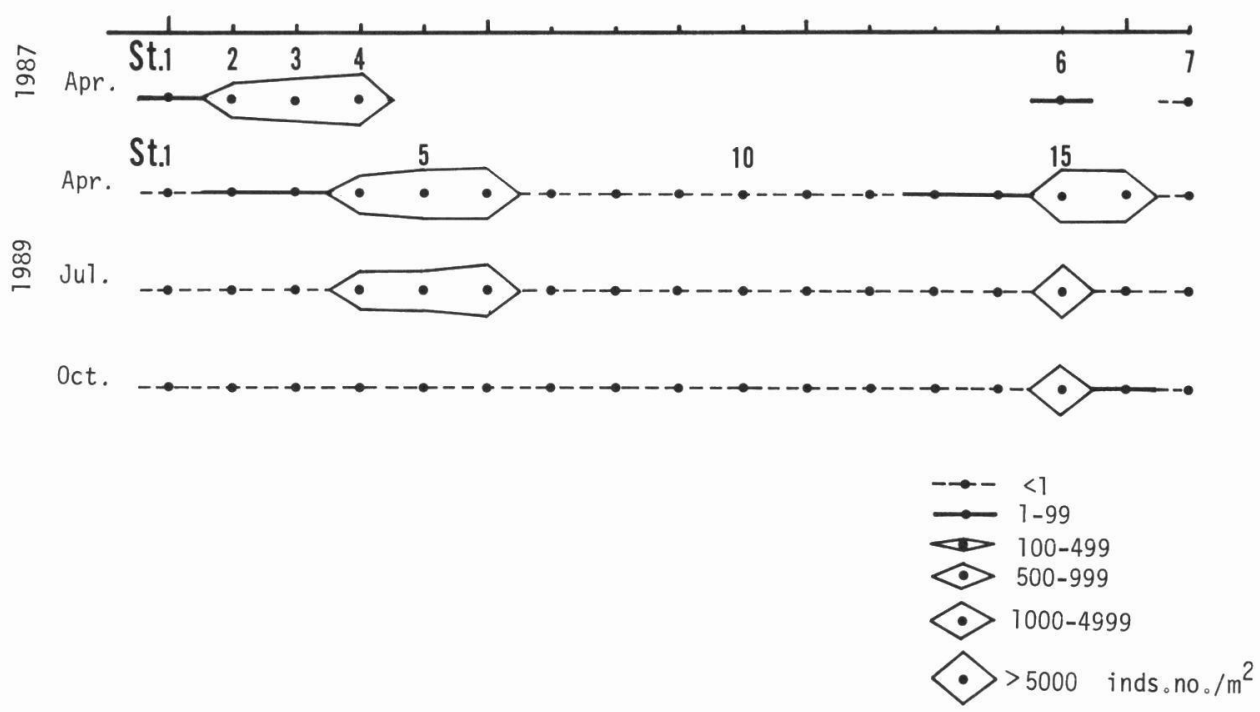

Fig. 4 Occurrence of the $M$. senhousia specimens in relation to the distance from the mouths upstream in the Ano and Shitomo Rivers. See Fig. 1 for the location of the stations in April/ May, 1987 and April, July and October, 1989 (the first and second series of sampling).

ment (occurrence of high density of the small-sized juveniles with shell length of less than $5.0 \mathrm{~mm}$ ) seems to be not restricted to a certain season, and its strength greatly flactuated for the three years: Strong recruitment was observed prior to April, in August and September, 1987, between April and November, 1988, and March and April, 1989, though the recruits with small numbers were almost always found through the years. No specimen was collected at the stations in September of the both years 1988 and 1989 due probably to flashing out by heavy rains coupled with typhoons (see Fig. 2).
In summary, it seems that the spatio-temporal distribution of the colonies of this species in the Ano and Shitomo Rivers is regulated by the constant recruits by dense colonies of the small-sized juveniles, and then by their mass mortality caused probably by heavy rains coupled with typhoons.

3. Cohorts of M. senhousia and their growth (third to fifth series of sampling)

With the help of AKAMINE (1985)'s method for analysing the monthly shell length composition of the specimens collected at Stn. 4 in the Shitomo 


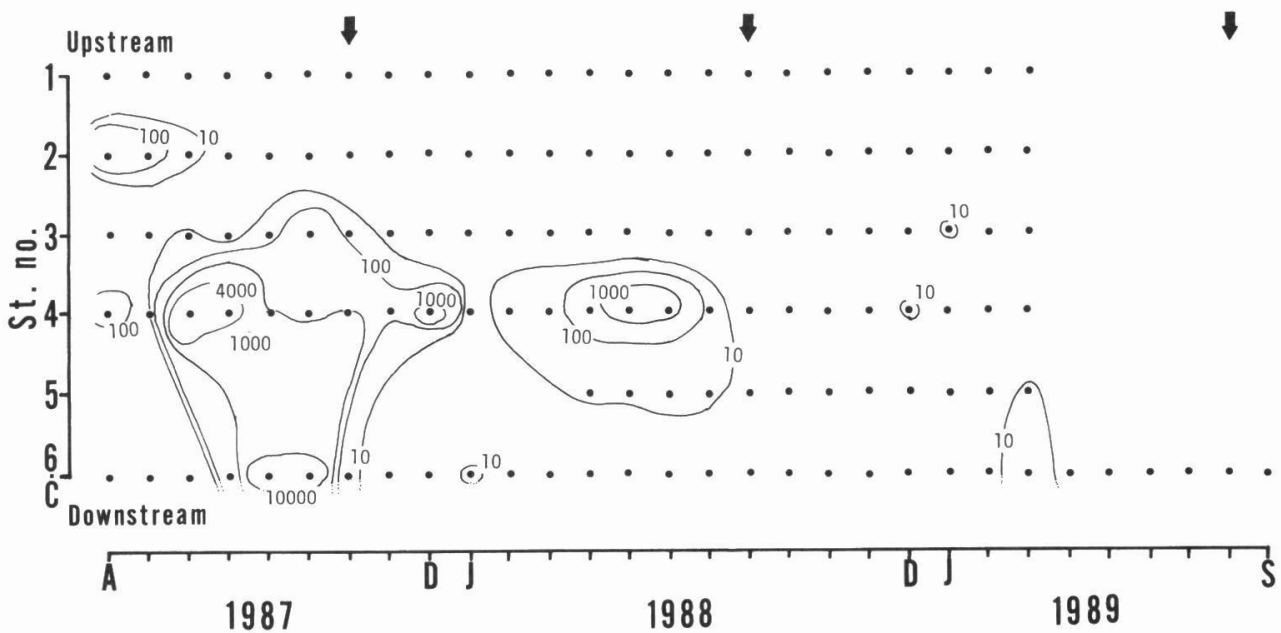

Fig. 5 Spatio-temporal distribution of densities of $M$. senhousia on the intertidal flats in the Ano River. Closed circles; sampling stations, Numerals; inds. $/ \mathrm{m}^{2}$, Arrows; typhoons passing close to Tsu City. See Fig. 1 for the location of the third to fifth series of sampling.

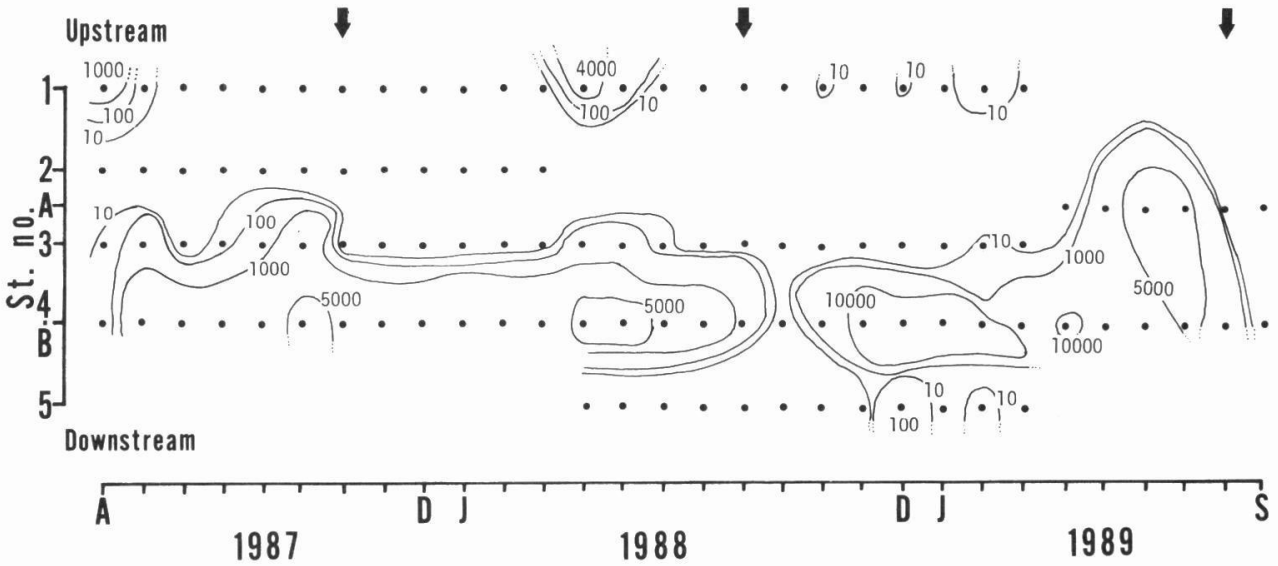

Fig. 6 Spatio-temporal distribution of densities of M. senhousia on the intertidal flats in the Shitomo River. Closed circles; sampling stations, Numerals; inds. $/ \mathrm{m}^{2}$, Arrows; typhoons passing close to Tsu City. See Fig. 1 for the location of the third to fifth series of sampling.

River where the dense colonies were found for the considerably longer period (Fig. 8), different cohorts and their growth could be traced.

Six cohorts, called A, B, C, D, E and F, respectively, were identified as shown in Fig. 9. The number and size of the cohorts considerably fluctuated from year to year. The cohorts differed much from each other in growth rate, maximal length size and longevity, though all the cohorts showed low growth in winter. In particular, longevity of the cohorts ranged in two months (the cohort F) to nearly one year (the cohort B). Collapsing of the cohort B in August, 1988 and of the all other cohorts in September, 1989 are well in accordance with heavy rains coupled with typhoons (see Fig. 2). 
The cohorts D and E at Stn. 4 of the Shitomo River correspond to the already mentioned strong recruitments in December, 1988 and in March to April, 1989, respectively (Figs. 7 and 9): The cohorts $\mathrm{A}$ to $\mathrm{C}$, and $\mathrm{F}$ do not originate from any of the strong recruitments (Figs. 7 and 9). Accordingly, the establishment of the cohorts of $M$. senhousia on the intertidal flats in the Ano and Shitomo Rivers does not depend directly on strength of the recruitment.

In summary, catastrophic episodes such as heavy rains coupled with typhoons, the timing and strength of which varied considerably in season and in year to year, prevent from establishment of recruits as long living cohorts in the intertidal flats.

According to TANAKA \& KIKUCHI (1978), the M. senhousia population in Tomoe Cove, Amakusa, showed remarkable seasonal and annual fluctuations of its density, and an annual cohort of each year was established, though longevity of each cohort considerably varied. This apparent difference between the $M$. senhousia populations at two sites (Tomoe Cove, and the Ano and Shitomo Rivers) would be in part caused by the fact that the specimens were collected from the subtidal zone at Tomoe Cove in TANAKA \& KIKUCHI (1978), while the present materials were from the intertidal zone at the mouths of the Ano and Shitomo Rivers. Much different from the subtidal zone where the species would not be exposed to intensive physical disturbance, environmental conditions on the intertidal zone, especially along the river mouth, show strong daily to seasonal fluctuations superimposed by catastrophic episodes occurring more or less
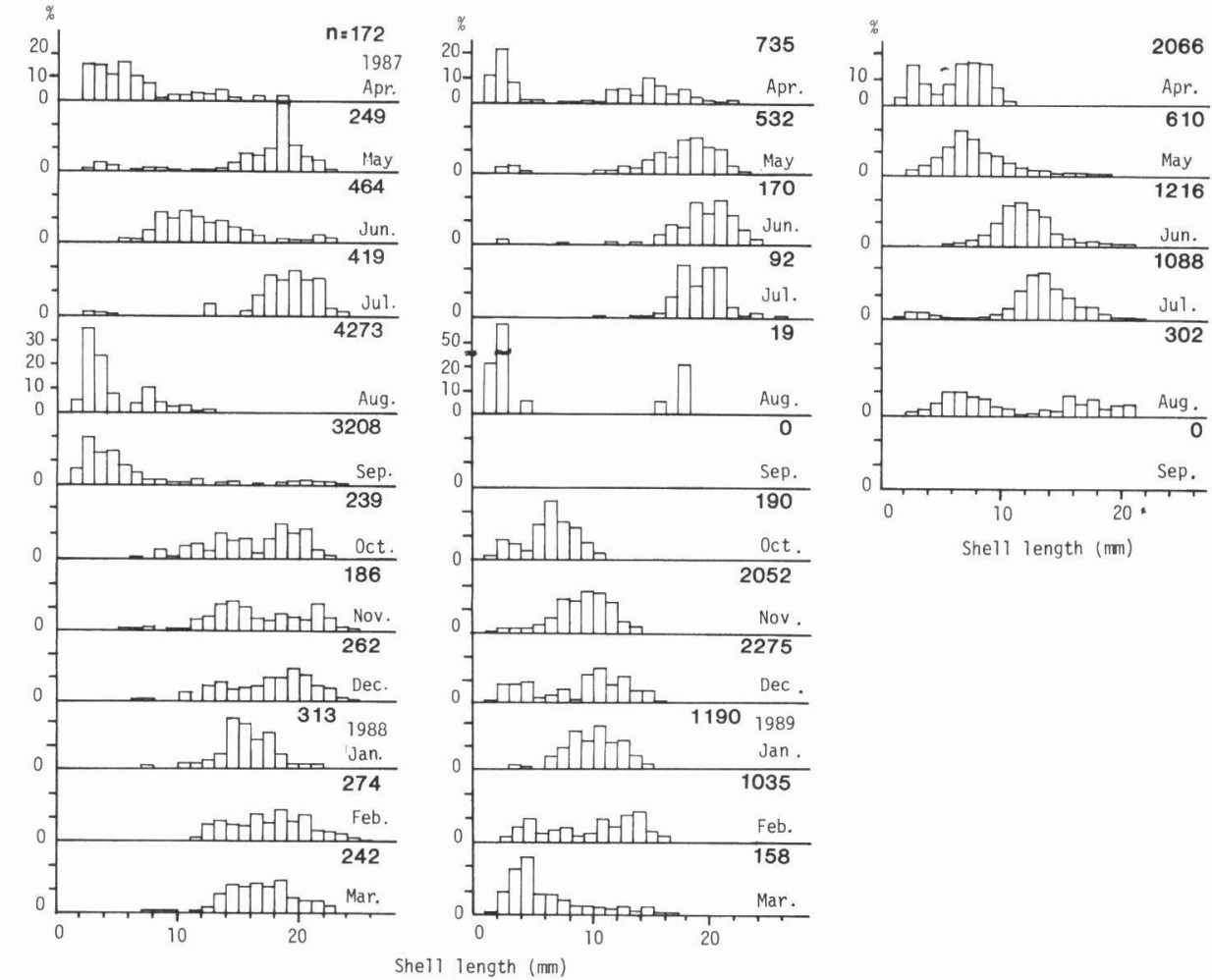

Fig. 7 Shell length distribution of the M. senhousia specimens collected at all sampling stations in the Ano and Shitomo Rivers. "n" indicates total individual numbers of the collected specimens. 
randomly in each year. Curiously, the species was not found in the intertidal zone at Tomoe Cove during the years studied by TANAKA \& KIKUCHI (1978), but is recently found there while disappearing from the subtidal zone due probably to the rapid progress of eutrophication through dense fish cultures (TANAKA, pers. comm.). To our knowledges, the species is not found in the subtidal zone along the mouths of the Ano and Shitomo Rivers. Furthermore, the species is in general found abundantly in the subtidal zone at the innermost part of
Tokyo Bay, though a small colony occurs in the intertidal zone (FUROTA, 1981). The reasons are not immediately apparent why distributional pattern of the species differs much according to locality as mentioned above. We continue to study for knowing the reasons why the species are found abundantly in the intertidal zone, but not in the subtidal zone, along the mouths of the Ano and Shitomo Rivers.

It has been known that spawning period of $M$. senhousia is comparatively long and lasts from May
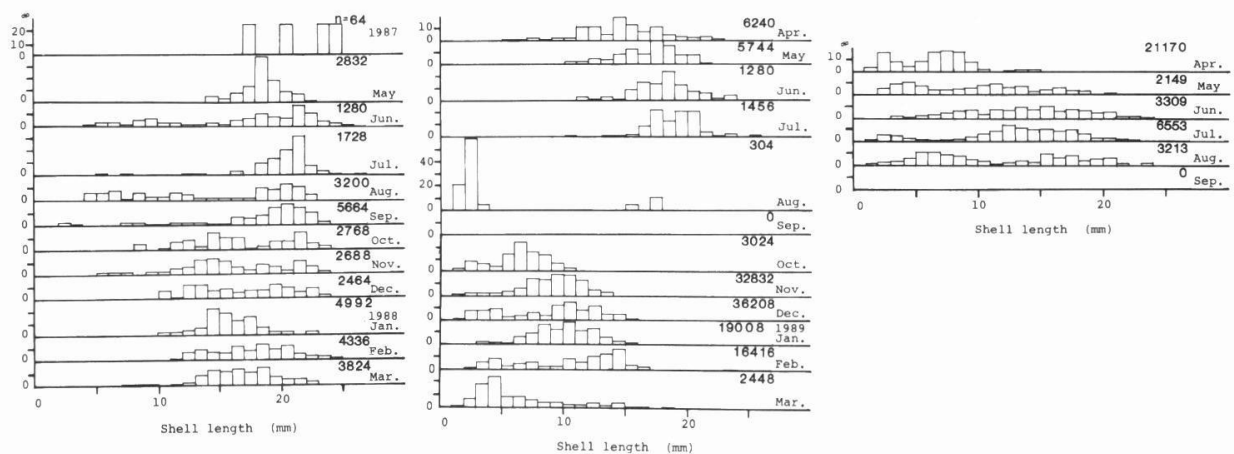

Fig. 8 Shell length distribution of the M. senhousia specimens collected at Stn. 4 in the Shitomo River. " $\mathrm{n}$ " indicates individual numbers per $\mathrm{m}^{2}$.

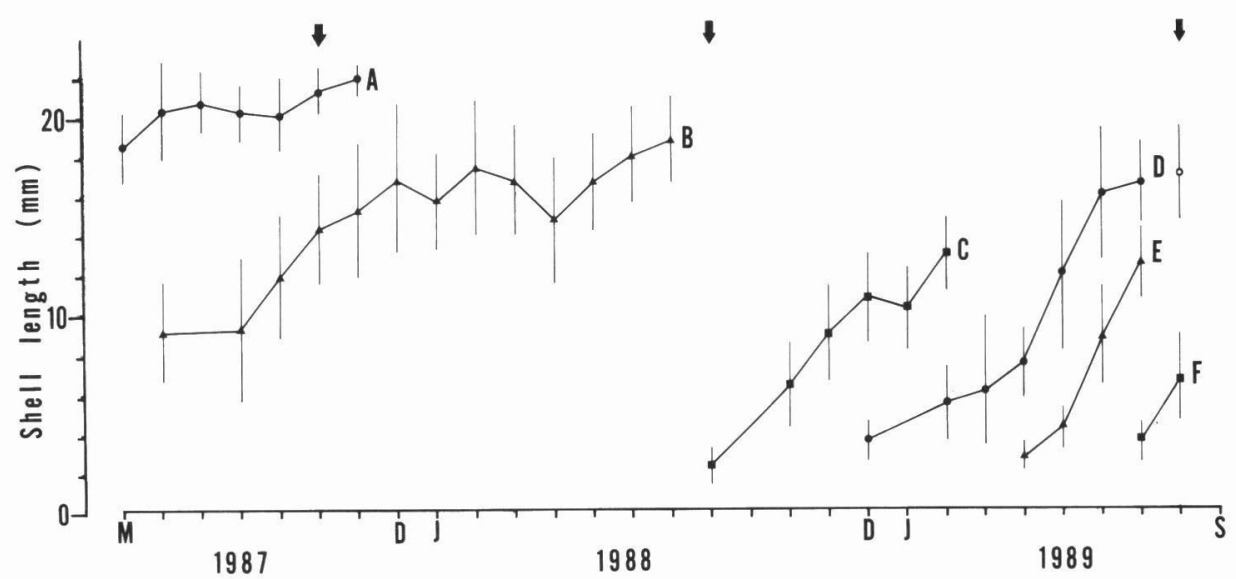

Fig. 9 Cohorts and their growth of the M. senhousia population based on the specimens collected at Stn. 4 in the Shitomo River. A-F; cohorts, Solid lines; standard deviation, Solid circles; a mode of the length, Open circles; a mode of the length undetermined whether belonging to the cohort $\mathrm{D}$ or to the cohort E, Arrows; typhoons passing close to Tsu City. 
to September with its main period in July to August (UCHIDA, 1965 ; KAWAHARA \& KATO, 1970 ; CHIBA \& OHSHIMA, 1976). KAWAHARA \& KATO (1970) reported that it took 25 days at $22^{\circ} \mathrm{C}$ to $25^{\circ} \mathrm{C}$ from spawning to larval settlement in the species. Then the recruits with shell length of more than $1.0 \mathrm{~mm}$ were observed during January to April in the Lake Nakaumi, during August to September in Tokyo Bay and the Lake Hamana, during January to May in Tomoe Cove, and during January in Hong Kong (KIKUCHI, 1964 ; CHIBA, 1965; MORTON, 1974 ; CHIBA \& OHSHIMA, 1976; TANAKA \& KIKUCHI, 1978 ; KIKUCHI \& TANAKA, 1978). On the other hand, the recruits with shell length of less than 1.0 $\mathrm{mm}$ were found through the year in Tokyo Bay according to $\mathrm{XU}$ (1983). These reports on seasonal appearance of the recruits of $M$. senhousia apparently are not consistent with each other. The present results from the both Ano and Shitomo Rivers, however, show that the success of the recruits is influenced by unpredictable physical disturbance, e. g., heavy rains caused by typhoons. The reported discrepancy disappears, if we can assume that there are also such kind of catastrophic events in other places, which occur variously according to localities.

\section{Acknowledgements}

The authors express their hearty thanks to Dr. A. KAWAMURA, Faculty of Bioresources of Mie University, for his encouragement through the present study. Thanks are due to the students of the Aquatic Ecology Laboratory of Mie University for cooperative works in sampling.

\section{References}

Aвbot, R. T., 1974. American Seashell, 2nd ed., Von Nostrand Reinhold Company, New York. 663 pp.

AKAmine, T., 1985. Considerations of the BASIC program to analyse the polymodal frequency distribution into normal distribution. Bull. Japan Sea Reg. Fish. Res. Lab., 35: 129-160 (in Japanese).

CHIBA, K., 1976. On the ecology of bivalve Mus. culus senhousia. Kaiyo Kagaku Monthly, $9: 229$ -233 (in Japanese).

CHIBA, K. and T. OHSHIMA, 1976. Distribution of Musculista senhousia in the Lake Hamana. Oral presentation at the 1976 annual meeting of Suisan Gakkai (in Japanese).

ChibA PREFECTURAL Fisheries ExPERIMENTAL STATION, 1965. Investigation on the Hototogisugai Musculista senhousia. In the Annual Report of Investigation on the Protected Waters in Chiba Prefecture, pp. 10-13 (in Japanese).

FOLK, R. T. and W. C. WARD, 1957. Brazos River bar: A study in the significance of grain size parameters. J. Sed. Petrol., 27 : 3-26.

FUROTA, T., 1981. Community structure of macrobenthos on tidal flats. Bull. Coast. Oceanogr., 18: 78-87 (in Japanese).

Hamamatsu Highschool Biology Club, 1983. Intertidal organisms in the Lake Hamana-Musculista senhousia and Limnopterna fortunei, 151 pp. (in Japanese).

ITO, N. and T. KAJIHARA, 1981a. The ecological study of the mussel, Musculista senhousia, in Yokosuka Harbor. 1. Distribution, population changes and total sulphide under the mussel nest. Mar. Fouling, 3: 37-42 (in Japanese).

ITO, N. and T. KAJIHARA, 1981b. The ecological study of the mussel, Musculista senhousia, in Yokosuka Harbor. 2. Structures of byssal threads and nest. Ibid., 3: 43-46 (in Japanese).

JOHNSON, R. G., 1974. Particulate matter at the sediment-water interface in coastal environments. J. Mar. Res., 32 : 313-330.

KAWAHARA, T. and D. KATO, 1970. Artificial spawning of Musculista senhousia and early development. Suisanzoshoku, 17:247-261 (in Japanese).

KIKUCHI, T., 1964. Ecology and biological production of Lake Nakaumi and adjacent waters. 3. Macrobenthic communities of Lake Shinji-ko and Lake Nakanoumi. Spec. Publ. Seto Mar. Biol. Lab., Ser. 2, Part 1: 21-44.

KIKUCHI, T. and M. TANAKA, 1978. Ecological studies on benthic macrofauna in Tomoe Cove, 
Amakusa. 1. Community structure and seasonal change of biomass. Publ. Amakusa Mar. Biol. Lab., 4 : 189-213.

KurodA, T., T. HABE and K. OYAMA, 1971. The Sea Shell of Sagami Bay, Maruzen, Tokyo, 1281 pp. (in Japanese).

Morton, B., 1974. Some aspects of biology, population dynamics, and functional morphology of Musculista senhousia BENSON (Bivalvia, Mytilidae). Pacific Sci., 28: 19-33.

TAKI, Y., 1952. The Hototogisugai Musculista senhousia. Suisankai, 809 : 21-24 (in Japanese).

TANAKA, M. and T.KIKUCHI, 1978. Ecological studies on benthic macrofauna in Tomoe Cove, Amakusa. 2. Production of Musculista senhousia (Bivalvia, Mytilidae). Publ. Amakusa Mar. Biol. Lab., 4 : 215-233.

UCHIDA, H., 1965. Growth of Musculista senhousia and its influence on Ruditapes philippinarum. Rep. Chiba Pref.Fish. Exp.Stn., 7:69-78 (in Japanese).

XU, C. R., 1983. Studies on the identification of larvae and juveniles of several bivalves, and their early life history. Ph.D.Dissertation, Tokyo 'University, 180 pp. (in Japanese).

\section{和文摘要}

河口干潟において毎月 1 回，3 年間にわたって採集 された試料にもとづいて，ホトトギスガイの個体群動 態を調べた。 小型の稚貝の集群や, 台風による激しい 降雨による大量死によって, ホトトギスガイの時空間 分布は著しい偏りを示した。従って, コホートの数や サイズは年によって激しく変動した。台風による激し い降雨が稚貝の生残に著しく影響し，これを生き残つ た稚貝のみがコホートの成立に寄与するので, ホトト ギスガイのコホートの成立は加入する稚貝数の多少に は依存していない.

\section{HIDEO SEKIGUCHI}

Faculty of Bioresources, Mie University 1515 Kamihama-cho, Tsu, Mie 514, Japan 